Article

\title{
Growth and Production of Lipids in Raphidocelis subcapitata Immobilized in Sodium Alginate Beads
}

\author{
Amel Benasla * and Robert Hausler \\ Station Expérimentale des Procédés Pilotes en Environnement, École de Technologie Supérieure, \\ Université du Québec, 1100, rue Notre-Dame Ouest Local A-1500, Montréal, QC H3C 1K3, Canada; \\ Robert.Hausler@etsmtl.ca \\ * Correspondence: amel.benasla.1@ens.etsmtl.ca; Tel.: +1-514-396-8800 (ext. 7541)
}

Received: 10 December 2019; Accepted: 17 January 2020; Published: 20 January 2020

\begin{abstract}
The growth and production of lipids in the green microalga Raphidocelis subcapitata immobilized in alginate gel are studied. The beads are made from alginate $(2 \% w / v)$ and $\mathrm{CaCl}_{2}(1 \% w / v)$. The dry weight, the concentration of cells, and the lipid content are determined after dissolution of the beads in a sodium phosphate buffer. The results show that variations in biomass do not reflect variations in the number of cells in $R$. subcapitata. Cells divide more rapidly $\left(G_{c}=3.45 \pm 0.3\right.$ days $)$ than biomass is produced $\left(\mathrm{G}_{\mathrm{m}}=4.1 \pm 0.4\right.$ days) during the exponential growth phase. Therefore, the average mass of the immobilized cells decreases until it reaches its minimum at the end of the exponential phase. Thus, during the stationary phase, cell division ceases while biomass production continues, and the average mass of the immobilized cells increases. In the present study, it is shown that this increase is due to the accumulation of lipids following the depletion of nitrates and phosphates in the culture medium. A lipid content of $24.7 \pm 2.5 \%(\mathrm{dcw})$ and a lipid productivity of $\mathrm{LP}=29.8 \pm 3.0 \mathrm{mg} / \mathrm{L} /$ day are recorded at the end of culture. These results suggest that immobilized R. subcapitata has promising potential for biodiesel production.
\end{abstract}

Keywords: biomass; cell division; lipid content; Raphidocelis subcapitata; alginate; $\mathrm{CaCl}_{2}$

\section{Introduction}

In response to the problems of climate change and greenhouse gas emissions in the atmosphere, microalgal biomass has emerged as a superior raw material and promising alternative for biodiesel production [1-4]. According to some estimates, the average lipid productivity of microalgae is 54 tons/ha/year, which is higher compared to oilseed crops, such as oil palm (3.62 tons/ha/year) and rapeseed ( 0.68 tons/ha/year) [2,5]. In addition, microalgae can use $\mathrm{CO}_{2}$ from the atmosphere, gases from various processes such as those from coal-fired power plants, or soluble carbonates with an efficiency 10 to 50 times greater than those of terrestrial plants [3,4,6]. Most importantly, growing microalgae for biodiesel production does not trigger a food-biofuel issue, which could lead the industry towards more sustainable development [7].

Great attention has been paid to certain species, including the green alga Raphidocelis subcapitata, because of their rapid growth and high level of lipid production [8,9]. Nevertheless, the high energy input required, particularly in the concentration and drying stage of biomass in the biodiesel production process, has made the possibility to market algocarbons questionable [10]. Production processes have evolved and new technologies, such as cell immobilization in natural polysaccharides, have been introduced into microalgae culture to facilitate their harvesting. The most frequently used are alginates, carrageenans, and agars because of their non-toxicity, biodegradability, and transparency 
to light, which helps to maintain the algae's photosynthetic activity [11-13]. In the case of alginate polycarboxylate extracted from brown algae, the polymer is mixed with microalgae cells, then the gelling of the beads is produced by cationic grafting in the presence of multivalent ions such as $\mathrm{CaCl}_{2}$ [14]. The beads obtained have a relatively large size compared to the free cells and can be easily separated from the culture medium by simple sieving without energy consumption. Thus, microalgal biomass will become easier to handle. However, in the literature, there is less work on the use of immobilized microalgae for biodiesel production compared to those using microalgae-free cultivation (Table 1). The objective of this work is to study the growth and production of lipids in the microalga Raphidocelis subcapitata immobilized in alginate gel with a view to its development into biodiesel. This species is characterized by its high lipid productivity $[8,9]$ and by the fixation of $\mathrm{CO}_{2}$ in the form of organic matter, thanks to light energy, thus contributing to its reduction in the atmosphere [15]. To our knowledge, no research projects have been published on the cultivation of $R$. subcapitata in alginate beads for possible use in the production of biodiesel.

Table 1. Various species of free versus immobilized microalgae used for biodiesel production.

\begin{tabular}{ccc}
\hline Microalgae & Type of Culture & Reference \\
\hline Parachlorella kessleri UTEX2229 & Free & {$[16]$} \\
Chlorella sp. & Free & {$[17]$} \\
Chlorella sorokiniana & Free & {$[18]$} \\
Chlorella vulgaris & Immobilized & {$[19]$} \\
Tetraselmis sp. & Free & {$[20]$} \\
Dunaliella tertiolecta & Free & {$[21]$} \\
Nannochloropsis oculata & Free & {$[22]$} \\
Phaeodactylum tricornutum & Free & {$[23]$} \\
Pseudokirchneriella subcapitata & Free & {$[9]$} \\
Botryococcus braunii & Immobilized & {$[24]$} \\
\hline
\end{tabular}

\section{Materials and Methods}

\subsection{Chemical Products}

Sodium alginate extracted from brown algae (No. 71238) and phosphate buffer components, sodium phosphate monobasic dihydrate $\mathrm{NaH}_{2} \mathrm{PO}_{4} \cdot 2 \mathrm{H}_{2} \mathrm{O}$ (No. 71505) and sodium phosphate dibasic dihydrate $\mathrm{Na}_{2} \mathrm{HPO}_{4} \cdot 2 \mathrm{H}_{2} \mathrm{O}$ (No. 71643), were supplied by Sigma-Aldrich ${ }^{\circledR}$ (Oakville, ON, Canada). Calcium chloride dihydrate $\mathrm{CaCl}_{2} \cdot 2 \mathrm{H}_{2} \mathrm{O}$ (No. 700912), used as a gelling medium [14,25-28], was supplied by Anachemia (Montréal, QC, Canada).

\subsection{Microalga and Culture Medium}

Raphidocelis subcapitata came from the Environment Canada Laboratory. The microalga was conserved and grown in a medium [29] prepared from five mother solutions whose composition (per liter) is as follows: (1) $25.5 \mathrm{~g} \mathrm{NaNO}_{3}$; (2) $14.7 \mathrm{~g} \mathrm{MgSO}_{4} .7 \mathrm{H}_{2} \mathrm{O}$; (3) $1.044 \mathrm{~g} \mathrm{~K}_{2} \mathrm{HPO}_{4}$; (4) $15 \mathrm{~g} \mathrm{NaHCO}_{3}$; (5) $10 \mathrm{~g} \mathrm{MgCl}_{2} \cdot 6 \mathrm{H}_{2} \mathrm{O} ; 4.4 \mathrm{~g} \mathrm{CaCl}_{2} \cdot 2 \mathrm{H}_{2} \mathrm{O} ; 0.185 \mathrm{~g} \mathrm{H}_{3} \mathrm{BO}_{3} ; 0.416 \mathrm{MnCl}_{2} \cdot 4 \mathrm{H}_{2} \mathrm{O} ; 3.28 \mathrm{mg} \mathrm{ZnCl} 2 ; 0.16 \mathrm{~g} \mathrm{FeCl}_{3}$; $1.428 \mathrm{mg} \mathrm{CoCl} 2 \cdot 6 \mathrm{H}_{2} \mathrm{O} ; 7.26 \mathrm{mg} \mathrm{Na} 2 \mathrm{MoO}_{4} \cdot 2 \mathrm{H}_{2} \mathrm{O} ; 0.012 \mathrm{mg} \mathrm{CuCl}$; and $0.3 \mathrm{~g} \mathrm{Na}_{2}$ EDTA. $2 \mathrm{H}_{2} \mathrm{O}$. From each nutrient solution, $10 \mathrm{~mL}$ was taken and transferred to an Erlenmeyer flask; the distilled water was then added to bring the volume to $1 \mathrm{~L}$. The $\mathrm{pH}$ of the medium was adjusted to 7.5. The culture medium was sterilized by an autoclave at $121^{\circ} \mathrm{C}$ for $20 \mathrm{~min}$.

\subsection{Cell Immobilization}

The immobilization of $R$. subcapitata cells in alginate gel was performed under sterile conditions from $2 \%(w / v)$ sodium alginate solutions, $\mathrm{CaCl}_{2} 1 \%(w / v)$, sterilized by autoclave $\left(121^{\circ} \mathrm{C}, 20 \mathrm{~min}\right)$ [28], and an algae suspension in the exponential growth phase of biomass concentration of about $1 \mathrm{~g} / \mathrm{L}$. 
A total of $100 \mathrm{~mL}$ of microalgae culture was concentrated by centrifugation $\left(4000 \mathrm{rpm}, 4{ }^{\circ} \mathrm{C}\right.$ for $10 \mathrm{~min})$; the pellet was recovered and washed three times in sterile saline water $(0.85 \%)$, with centrifugation between each wash. Cells were then suspended in $50 \mathrm{~mL}$ of sterile saline water $(0.85 \%)$. The algae suspension was finally mixed with $50 \mathrm{~mL}$ of sodium alginate solution and gently homogenized [28,30]. The mixture was transferred into a sterile $20 \mathrm{~mL}$ syringe equipped with a 20 G $0.9 \times 40 \mathrm{~mm}$ needle (Braun, Melsungen, Germany) and expelled dropwise into the $\mathrm{CaCl}_{2}$ solution. The beads generated were left in the $\mathrm{CaCl}_{2}$ solution for $30 \mathrm{~min}$ to complete the gelation. After this, they were harvested using a sterile metal sieve and then washed with sterile distilled water.

\subsection{Culture Conditions}

The beads containing the microalgae were aseptically transferred into a 2 L Erlenmeyer flask, previously sterilized by an autoclave $\left(121^{\circ} \mathrm{C}, 20 \mathrm{~min}\right)$, containing $1 \mathrm{~L}$ of sterile culture medium. They were then placed in an incubator equipped with a stirring table (INFORS HT Ecotron, Montréal, $\mathrm{QC}$, Canada), providing standard culture conditions, agitation (100 rpm), and temperature $\left(25 \pm 1{ }^{\circ} \mathrm{C}\right)$.

The experiment was carried out under a photoperiod of $24 \mathrm{~h}$ of light for $0 \mathrm{~h}$ of darkness (24/0; $\mathrm{L} / \mathrm{D})$. A white fluorescent lamp (KF15T8CW-PROJECT PAK 15W) was used as a light source. It was installed vertically, thus providing lighting of 4000-5000 lux (light quantum flux of approximately $56 \mu \mathrm{mol} /\left(\mathrm{m}^{2} \mathrm{~s}\right)$ ).

In order to avoid cell sedimentation and to prevent the depletion of the medium in $\mathrm{CO}_{2}$, the cultures were heavily bubbled (145 L of air/liter of culture/hour). $\mathrm{CO}_{2}$ was supplied by an air pump (MARINA 300). The air was filtered by a $0.45 \mu \mathrm{m}$ porosity filter (Fischer Scientific).

\subsection{Growth Monitoring}

The growth monitoring of the cells immobilized in the beads was carried out by measuring the cell concentration and determining the dry weight over a period of 10 days. Each day, ten beads were removed aseptically from the Erlenmeyer flask and transferred in $20 \mathrm{~mL}$ of sterile sodium phosphate buffer $(\mathrm{pH}=6.0)$, at a concentration of $50 \mathrm{mM}$. They were then incubated at room temperature for $24 \mathrm{~h}$. This step allowed the dissolution of the beads and consequently the release of cells $[28,31]$.

The number of cells was determined by measuring the optical density at $685 \mathrm{~nm}$ using a spectrophotometer (Varian cary 300 bio visible UV spectrophotometer). The relationship between the $\mathrm{OD}_{685}(\mathrm{y})$ and the concentration of $R$. subcapitata cells $(\mathrm{x})$ is given by the following equation: $y=0.3572 x\left(R^{2}=0.9978\right)$.

The determination of the dry weight was carried out by filtration of the algae suspension on a pre-weighed fiberglass filter (Wathman filter, $1.2 \mu \mathrm{m}$ ) (METTLER AT261 balance). The cells were washed with $100 \mathrm{~mL}$ of sterile distilled water. The filter was then placed in the oven at $80^{\circ} \mathrm{C}$ for $24 \mathrm{~h}$, cooled in a desiccator for $15 \mathrm{~min}$, and then weighed again. The biomass concentration represents the average of two tests. It was calculated from the difference in mass of the filter divided by the volume of the sample and was expressed in $\mathrm{g} / \mathrm{L}$, according to the following equation:

$$
\mathrm{Cx}(g / L)=\frac{m_{2}-m_{1}}{\text { Vsample }} \times 10^{3}
$$

where $m_{1}$ : mass of the filter. $m_{2}$ : mass of the filter containing the microalgae.

\subsection{Calculation of Growth Parameters}

The immobilized $R$. subcapitata culture is performed in batch. The optimal cell division rate $\left(\mu_{\mathrm{c}}\right)$ and biomass production rate $\left(\mu_{\mathrm{m}}\right)$ were calculated during the exponential growth phases according to the following equation [28,32]:

$$
\mu_{c}\left(\text { day }^{-1}\right)=\frac{\ln \left(N_{2} / N_{1}\right)}{t_{2}-t_{1}}
$$


where $N_{1}$ and $N_{2}$ are defined as the number of cells (cell/L) at time $t_{1}$ and $t_{2}$, respectively.

$$
\mu_{m}\left(\operatorname{day}^{-1}\right)=\frac{\ln \left(M_{2} / M_{1}\right)}{t_{2}-t_{1}}
$$

where $M_{1}$ and $M_{2}$ are defined as biomass $(\mathrm{g} / \mathrm{L})$ at time $t_{1}$ and $t_{2}$, respectively.

The doubling time of the microalgae cells ( $G_{\mathrm{c}}$ : generation time) and the biomass doubling time $\left(G_{\mathrm{m}}\right)$ are calculated according to the following formula [33]:

$$
G_{c}=\ln 2 / \mu_{c \max }
$$

$G_{\mathrm{c}}$ : generation time (day); ln: natural logarithm; $\mu_{\mathrm{c}}$ : specific growth rate $\left(\right.$ day $\left.^{-1}\right)$.

$$
G_{m}=\ln 2 / \mu_{m \max }
$$

$G_{\mathrm{m}}$ : Biomass doubling time (day); ln: natural logarithm; $\mu_{\mathrm{m}}$ : specific rate of biomass production $\left(\right.$ day $^{-1}$ ).

\subsection{Lipid Extraction from Immobilized Microalgae}

The extraction of total lipids was performed according to the whole cell analytical method (WCA) described by Van Vooren et al. [34]. It is based on the use of a mixture of apolar (chloroform) and polar (methanol) solvents in proportions 2:1 (v/v). Methanol allows the bursting of microalgae, thus making the lipids accessible to chloroform, which leads to the production of a complete lipid extract.

The choice of this method is justified by its numerous advantages compared to the methods of Folch [35] and Bligh and Dyer [36], which are recognized as reference techniques of extraction of total lipids. The WCA method is faster, simpler to perform, can be applied to a small sample volume, and ultimately achieves a better extraction yield [16].

After dissolving the beads (10 beads) as described above (Section 2.5), the resulting algal suspension was centrifuged for $10 \mathrm{~min}$ at $4000 \mathrm{rpm}$ at $4{ }^{\circ} \mathrm{C}$. Then, the supernatant was removed and $20 \mu \mathrm{L}$ of butylated hydroxytoluene (BHT) at $20 \mu \mathrm{g} / \mu \mathrm{L}$ were added to the pellet containing the whole cells of microalgae in order to prevent lipid oxidation during the extraction. The extraction was carried out in glass tubes with $6 \mathrm{~mL}$ of $\mathrm{CHCL}_{3} / \mathrm{MeOH}$ mixture 2:1 $(v / v)$ which were added in three times ( $2 \mathrm{~mL}$ successively). After each addition of solvents, the tubes were vortexed for $10 \mathrm{~s}$ and then placed in an ultrasonic bath (BRANSON 5200) for $30 \mathrm{~s}$ to improve the extraction yield. In fact, the ultrasounds emitted generate bubbles in the solvent mixture; the bursting thereof in the vicinity of the cells makes it possible to maximize the extraction of the lipids contained inside the microalgae. The tubes were thus covered with aluminum foil and kept shaking on a pendulum for $6 \mathrm{~h}$ in the dark in order to ensure the complete extraction of the lipids. The evaporation of the extraction solvent was carried out in an oven at $60^{\circ} \mathrm{C}$ for $6 \mathrm{~h}$. The tubes were then cooled in a desiccator for $20 \mathrm{~min}$ and weighed to determine the weight of dry matter obtained corresponding to the total lipids extracted. The level of fatty acids in the biomass represents the average of two tests and is given by the following formula:

$$
\text { Percentage mass of total lipids \% }(\mathrm{dcw})=\frac{\text { Mass of total lipids extract }(\mathrm{g})}{\text { Dry weight of cells }(\mathrm{g})} \times 100
$$

\subsection{Calculating Lipid Productivity}

The lipid productivity (LP) is calculated according to the following equation:

$$
\mathrm{LP}(\mathrm{mg} / \mathrm{L} / \text { day })=\frac{C_{2} B_{2}-C_{1} B_{1}}{t_{2}-t_{1}}
$$


where $C_{1}$ is the lipid content of microalgae (mg of lipids/mg of dry of cells) at $\mathrm{t}_{1}$ and $C_{2}(\mathrm{mg}$ of lipids/mg of dry of cells) is that at $t_{2} . B_{1}$ and $B_{2}$ are the biomass concentrations $(\mathrm{mg} / \mathrm{L})$ at time $\mathrm{t}_{1}$ and $t_{2}$, respectively.

\subsection{Measurement of Nitrates in the Culture Medium}

The determination of the nitrate concentration in the culture medium during the growth period of immobilized microalgae (10 days) was carried out according to a standard method [37]. Each day, $1 \mathrm{~mL}$ of culture medium was removed from the Erlenmeyer flask and centrifuged $\left(4000 \mathrm{rpm}, 4{ }^{\circ} \mathrm{C}\right.$ for $10 \mathrm{~min}$ ) to remove free microalgae cells that can be relegated from the beads. The supernatant was recovered, and the nitrate concentration was estimated by measuring the absorbance at $220 \mathrm{~nm}$ using the spectrophotometer (Varian cary 300 bio visible UV spectrophotometer). Since organic matter dissolved in the culture medium can also absorb UV light at $220 \mathrm{~nm}$, and thus distort the nitrate assay results, the absorbance of the sample was also measured at $275 \mathrm{~nm}$. Indeed, at this wavelength, only the dissolved organic matter absorbs.

The absorbance of nitrates was calculated as follows:

$$
A_{\text {nitrate }}=A_{220 n m}-2 A_{275 n m}
$$

A solution of sodium nitrate $\left(\mathrm{NaNO}_{3}\right)$ at different concentrations was used to plot the calibration curve.

\subsection{Measurement of Phosphates in the Culture Medium}

The determination of phosphate ions in the culture medium during the 10 days of culture of the immobilized microalgae was carried out according to the method of Murphy and Riley [38] with ascorbic acid.

\subsubsection{Principle of the Method}

Ammonium molybdate and potassium antimonyl tartrate react in acidic medium with orthophosphate to form an antimonyl-phosphate-molybdate complex, which is reduced by acid ascorbic acid to céruléomolybdic, a blue colored complex whose intensity is proportional to the phosphate concentration and is measured using a spectrophotometer (Varian cary 300 bio UV visible spectrophotometer) at $880 \mathrm{~nm}$.

\subsubsection{Reagents}

- $\quad$ Sulfuric acid, $\mathrm{H}_{2} \mathrm{SO}_{4}, 5 \mathrm{~N}$.

- $\quad$ Potassium antimonyl tartrate solution, $\mathrm{K}(\mathrm{SbO}) \mathrm{C}_{4} \mathrm{H}_{4} \mathrm{O}_{6}, 1 / 2 \mathrm{H}_{2} \mathrm{O}, 3.42 \mathrm{~g} / \mathrm{L}$.

- $\quad$ Ammonium molybdate solution, $\left(\mathrm{NH}_{4}\right)_{6} \mathrm{Mo}_{7} \mathrm{O}_{24}, 4 \mathrm{H}_{2} \mathrm{O}, 40 \mathrm{~g} / \mathrm{L}$.

- $\quad$ Ascorbic acid, $0.1 \mathrm{M}$.

Combined reagent: for $100 \mathrm{~mL}$ of combined reagent, the above reagents were mixed in the following order and in the following proportions: $50 \mathrm{~mL} \mathrm{H}_{2} \mathrm{SO}_{4}, 5 \mathrm{~N}, 5 \mathrm{~mL}$ potassium antimonyl tartrate solution, $15 \mathrm{~mL}$ ammonium molybdate solution, and $30 \mathrm{~mL}$ ascorbic acid. The resulting mixture was stable for $4 \mathrm{~h}$.

\subsubsection{Procedure}

Each day, $5 \mathrm{~mL}$ of culture medium were taken from the Erlenmeyer flask. After centrifugation at $4000 \mathrm{rpm}$ at $4{ }^{\circ} \mathrm{C}$ for $10 \mathrm{~min}$, the supernatant was collected in a $20 \mathrm{~mL}$ graduated flask to which $800 \mu \mathrm{L}$ of combined reagent was added. The solution was kept at room temperature for about $20 \mathrm{~min}$ before reading the absorbance at $880 \mathrm{~nm}$ using the spectrophotometer (Varian cary 300 bio visible UV spectrophotometer). 
A solution of potassium hydrogen phosphate $\left(\mathrm{K}_{2} \mathrm{HPO}_{4}\right)$ at different concentrations was used to plot the calibration curve.

\section{Results}

\subsection{Growth of R. subcapitata Immobilized in Alginate Beads}

Variations in the number of cells of immobilized R. subcapitata (Figure 1a) show a classical pattern of a discontinuous culture with an exponential growth phase which stops after the seventh day of culture, followed by a short slowing and then a stationary phase. The cell division rate and the generation time during the exponential phase of growth, are $\mu_{\mathrm{c}}=0.20 \pm 0.02 \mathrm{day}^{-1}$ and $G_{\mathrm{c}}=3.45 \pm 0.3$ days, respectively.

The biomass variations of immobilized $R$. subcapitata (Figure $1 \mathrm{~b}$ ) show an increase in the amount of biomass produced by microalgae in the alginate beads from the first days of culture. The rate of biomass production during the exponential phase of growth is $\mu_{\mathrm{m}}=0.17 \pm 0.02$ day $^{-1}$ and the generation time is $G_{m}=4.1 \pm 0.4$ days. As a result, biomass values continue to increase after the seventh day of cultivation, and stable biomass production was not reached, even on the last day of cultivation.

The comparison of the doubling time of the microalgae cells $\left(G_{c}=3.45 \pm 0.3\right.$ days $)$ and the doubling time of the biomass ( $G_{\mathrm{m}}=4.1 \pm 0.4$ days) shows that for the growth of $R$. subcapitata in the alginate gel, the number of cells increases more rapidly than biomass production during the exponential growth phase. Consequently, the average mass of the immobilized cells decreases until it reaches its minimum at the end of the exponential phase (Figure 1c). This is justified by the asexual reproduction of the cells. Like all microalgae, $R$. subcapitata is divided by mitosis; the size of the cells then decreases until they can no longer divide.
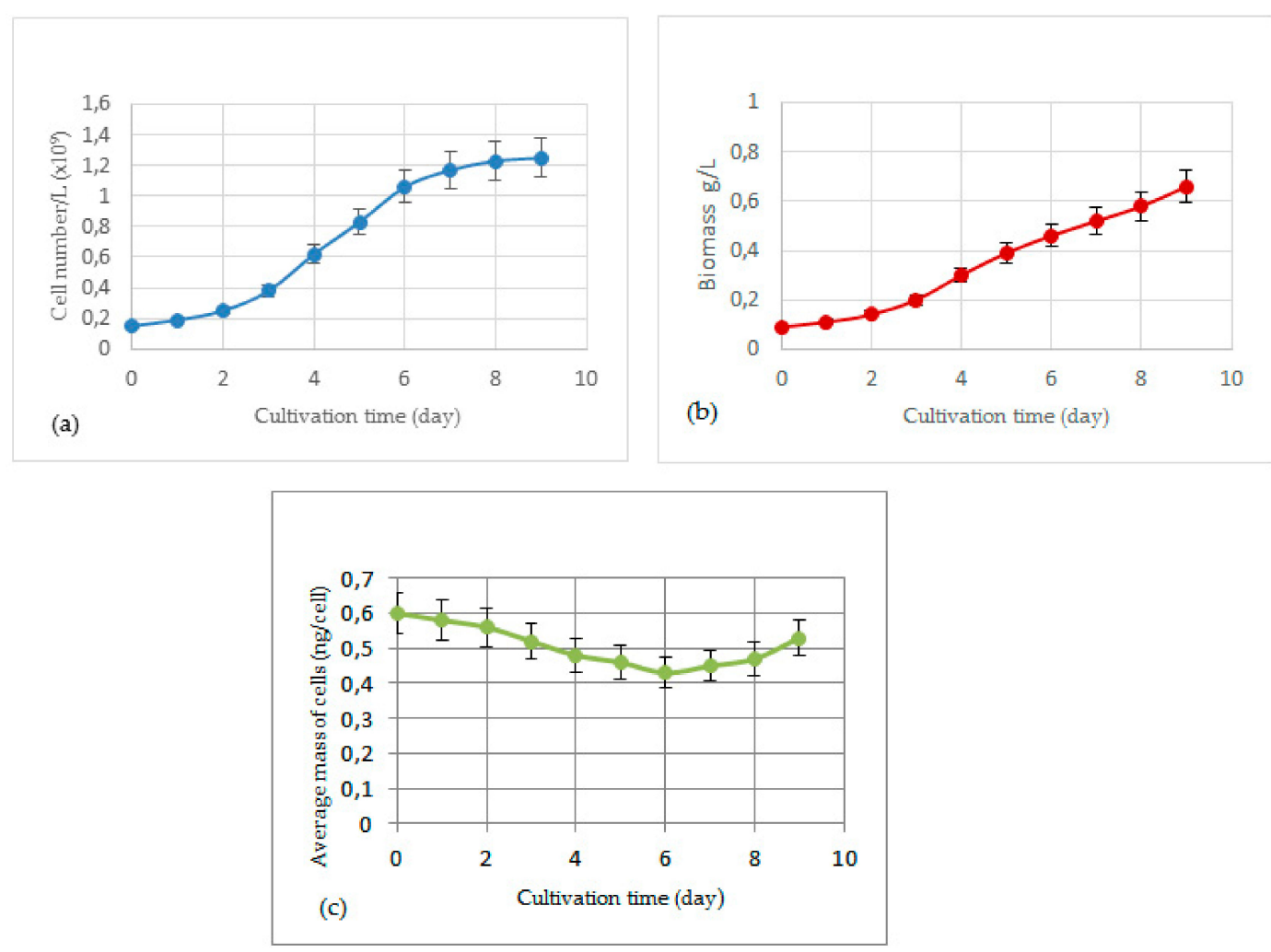

Figure 1. Growth of R. subcapitata immobilized in alginate beads over a period of 10 days (culture performed in batch and in duplicate): (a) variations in the number of cells; (b) variations in biomass; (c) variations of the average mass of cells. $t_{0}=d_{1}$. 
In addition, during the last three days of culture, cell division ceases while biomass production continues, and the average cell mass increases. Since the culture of microalgae is carried out in batch, this increase could be due to the accumulation of lipids following the depletion of one of the nutrients essential for growth, such as phosphorus or nitrogen. Indeed, the accumulation of lipids in response to this stress was observed in free R. subcapitata [39] and in other species of microalgae [39,40] including Chlorococcum oleofaciens, Scenedesmus almeriensis, and Nannochloropsis sp. F \& M-M24.

The production of lipids in immobilized $R$. subcapitata was then studied with the monitoring of the nitrate and phosphate concentrations in the culture medium during the whole culture period.

\subsection{Production of Total Lipids in R. subcapitata Immobilized in Alginate Beads}

Figure 2 shows the production of total lipids in immobilized R. subcapitata with monitoring of nitrate and phosphate concentrations in the culture medium, over a period of 10 days. When nitrates and phosphates are available in the culture medium (Figure 2a,b), a slight increase in lipid content is noted (Figure 2c) from $13.3 \pm 1.3 \%$ (dcw) (first day) to $15.3 \pm 1.5 \%$ (dcw) (seventh day), with lipid productivity, $\mathrm{LP}=9.5 \pm 1.0 \mathrm{mg} / \mathrm{L} /$ day. After the seventh day, the nitrates and phosphates are exhausted in the culture medium (Figure 2a,b) and a lipid accumulation is observed (Figure 2c). A lipid content of $24.7 \pm 2.5 \%$ (dcw) is recorded at the end of the experiment with lipid productivity (LP) of $29.8 \pm 3.0 \mathrm{mg} / \mathrm{L} /$ day.
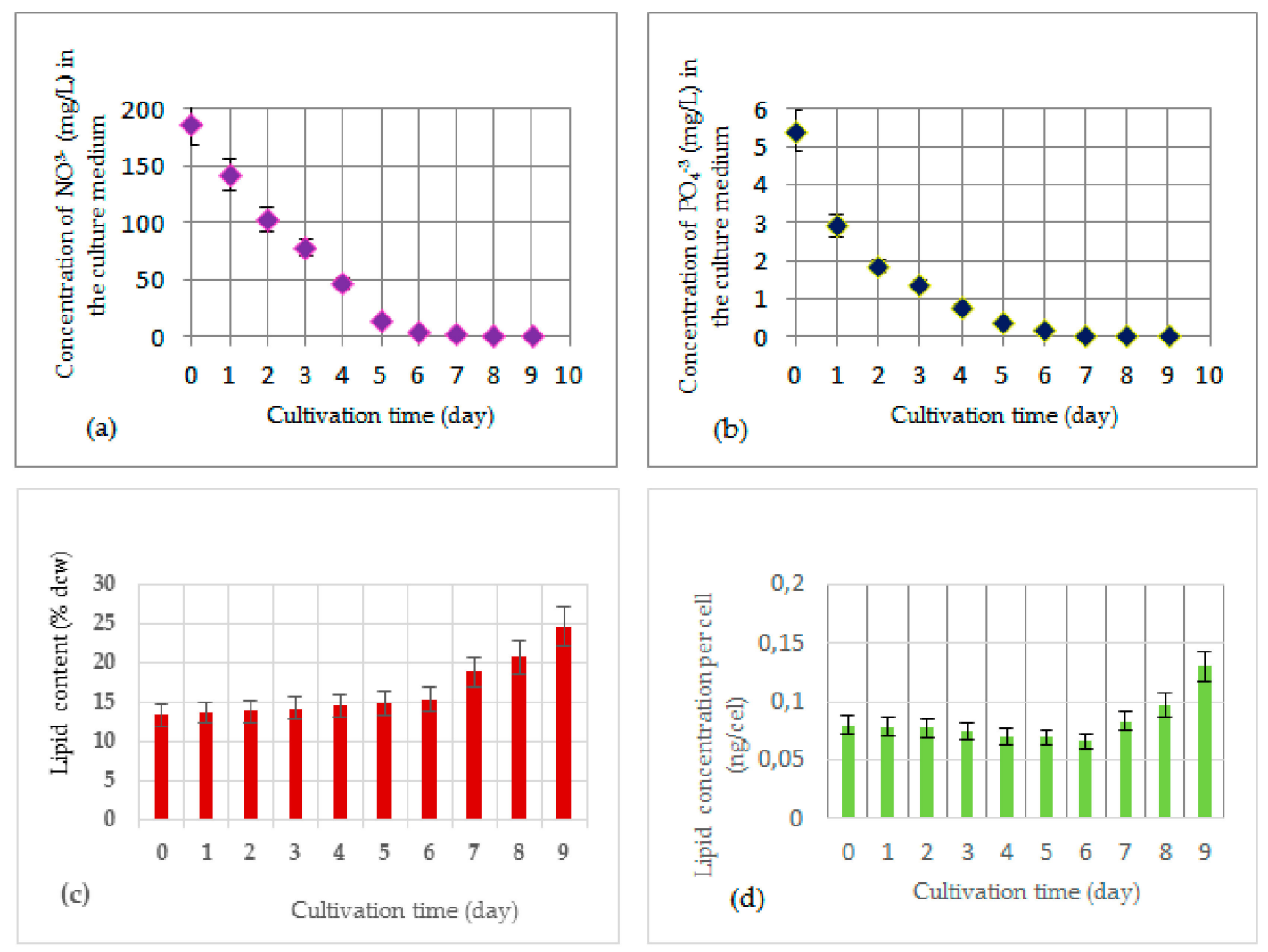

Figure 2. Production of total lipids in R. subcapitata immobilized in alginate beads, over a period of 10 days (culture performed in batch and in duplicate). (a) Nitrate consumption; (b) phosphate consumption; (c) variations in lipid content per dry weight of cells; (d) variations in lipid concentration per cell. $t_{0}=d_{1}$.

Despite variations in lipid concentration per microalgae cell, Figure $2 \mathrm{~d}$ shows a progressive decrease in concentration during the first days of culture, reaching a minimum value of $0.066 \pm 0.006 \mathrm{ng} / \mathrm{cell}$ on the seventh day (a decrease of approximately $17.5 \pm 1.7 \%$ ). This decrease results from the decrease in the mean mass of cells during their division (Figure 1c). After this, when the nitrates and phosphates 
are depleted in the culture medium (Figure 2a,b), the lipid concentration per cell is increased to $0.13 \pm 0.01 \mathrm{ng} / \mathrm{cell}$ on the last day of culture. It should be noted that the accumulation of lipids was stimulated as soon as nitrates and phosphates were depleted in the culture medium. This implies that de novo fatty acid synthesis was activated rapidly due to the lack of medium in these two elements.

These results confirm the results obtained above (Figure 1). The increase in biomass production during the stationary phase of growth (Figure $1 \mathrm{~b}$ ) is due to the accumulation of lipids following the depletion of nitrates and phosphates in the culture medium. Indeed, the storage of lipids results from an imbalance between the flow of carbon, resulting from photosynthesis, and the flow of nitrogen and phosphorus necessary for growth. When the cell is deficient in these elements, it does not immediately interrupt the acquisition of $\mathrm{CO}_{2}$ necessary for photosynthesis, as it cannot use it to produce proteins; it stores this flow, in the form of lipids [41-43].

Our results show that $R$. subcapitata immobilized in the alginate gel has the ability to accumulate lipids in response to nitrogen and phosphorus limitations. The value obtained in this study (accumulation of $24.7 \pm 2.5 \%(\mathrm{dcw})$ at the end of culture), under standard culture conditions, is encouraging since, according to the literature, the lipid contents of $R$. subcapitata would be between $12 \%$ and $41 \%$ of the dry weight, depending on the culture conditions and the concentrations of nitrates and phosphates in the medium $[39,44]$.

\section{Conclusions}

The results of this study suggest that the green microalga Raphidocelis subcapitata immobilized in alginate gel has promising potential for the production of biodiesel. Indeed, the strain has the ability to accumulate lipids in response to the depletion of nitrates and phosphates in the culture medium. The values obtained, under standard culture conditions, are encouraging. A lipid content of $24.7 \pm 2.5 \%$ (dcw) was recorded at the end of culture, with a lipid productivity (LP) of $29.8 \pm 3.0 \mathrm{mg} / \mathrm{L} /$ day.

In future work, it would be interesting to individually evaluate the effect of each element (nitrates, phosphates) on biomass production and lipid accumulation in order to optimize its growing conditions. This could significantly improve the yield of the species.

Author Contributions: A.B. and R.H. designed and developed the study. A.B. performed the experiments, collected and analyzed the data, and drafted the manuscript. R.H. supervised the work, provided advice on methodology and results, and revised the manuscript. All authors have read and agreed to the published version of the manuscript.

Funding: This research was funded by the Government of Canada grant number RGPIN 157382-11 And The APC was funded by Natural Sciences and Engineering Research Council of Canada (NSERC).

Acknowledgments: We would like to thank the Natural Sciences and Engineering Research Council of Canada (NSERC) for funding this research.

Conflicts of Interest: The authors declare no conflicts of interest.

\section{References}

1. Gavrilescu, M.; Chisti, Y. Biotechnology-A sustainable alternative for chemical industry. Biotechnol. Adv. 2005, 23, 471-499. [CrossRef] [PubMed]

2. Chisti, Y. Biodiesel from microalgae. Biotechnol. Adv. 2007, 25, 294-306. [CrossRef] [PubMed]

3. Khan, S.A.; Hussain, M.Z.; Prasad, S.; Banerjee, U.C. Prospects of biodiesel production from microalgae in India. Renew. Sustain. Energy Rev. 2009, 13, 2361-2372. [CrossRef]

4. Li, Y.; Horsman, M.; Wu, N.; Lan, C.Q.; Dubois-Calero, N. Biocatalysts and bioreactor design. Biotechnol. Prog. 2008, 24, 815-820.

5. Lam, M.K.; Lee, K.T. Renewable and sustainable bioenergies production from palm oil mill effluent (POME): Win-win strategies toward better environmental protection. Biotechnol. Adv. 2011, 29, 124-141. [CrossRef]

6. Doré-Deschênes, F. Utilisation des Microalgues Comme Source d'énergie Durable; Université de Sherbrooke: Sherbrooke, QC, Canada, 2009. 
7. Cantin, I. La Production de Biodiesel à Partir des Microalgues Ayant un Métabolisme Hétérotrophe; Canada Centre Universitaire de Formation en Environnement Université de Sherbrooke: Sherbrooke, QC, Canada, 2010.

8. Patil, V.; Källqvist, T.; Olsen, E.; Vogt, G.; Gislerød, H.R. Fatty acid composition of 12 microalgae for possible use in aquaculture feed. Aquac. Int. 2007, 15, 1-9. [CrossRef]

9. Gonçalves, A.L.; Pires, J.C.; Simões, M. Lipid production of Chlorella vulgaris and Pseudokirchneriella subcapitata. Int. J. Energy Environ. Eng. 2013, 4, 14. [CrossRef]

10. Sander, K.; Murthy, G.S. Life cycle analysis of algae biodiesel. Int. J. Life Cycle Assess. 2010, 15, 704-714. [CrossRef]

11. Moreira, S.M.; Moreira-Santos, M.; Guilhermino, L.; Ribeiro, R. Immobilization of the marine microalga Phaeodactylum tricornutum in alginate for in situ experiments: Bead stability and suitability. Enzym. Microb. Technol. 2006, 38, 135-141. [CrossRef]

12. Cao, Y.R.; Liu, Z.; Cheng, G.L.; Jing, X.B.; Xu, H. Exploring single and multi-metal biosorption by immobilized spent Tricholoma lobayense using multi-step response surface methodology. Chem. Eng. J. 2010, 164, 183-195. [CrossRef]

13. Moreno-Garrido, I. Microalgae immobilization: Current techniques and uses. Bioresour. Technol. 2008, 99, 3949-3964. [CrossRef] [PubMed]

14. Draget, K.I.; Steinsvåg, K.; Onsøyen, E.; Smidsrød, O. Na- and K-alginate; effect on Ca2+-gelation. Carbohydr. Polym. 1998, 35, 1-6. [CrossRef]

15. Pires, J.; Gonçalves, A.; Martins, F.; Alvim-Ferraz, M.; Simões, M. Effect of light supply on CO2 capture from atmosphere by Chlorella vulgaris and Pseudokirchneriella subcapitata. Mitig. Adapt. Strateg. Glob. Chang. 2014, 19, 1109-1117. [CrossRef]

16. Taleb, A. Production de Biodiesel à Partir des Microalgues: Recherche des Souches Accumulatrices des Lipides et Optimisation des Conditions de Culture en Photobioréacteurs. Ph.D. Thesis, Degree-Granting University, Nantes, France, 2015.

17. Rahbani, J.N.; Salameh, D.F.; Rahbani, J.N. Identifier des microalgues pour le traitement des eaux usées et la production de biocarburant. Available online: https://scholar.google.com/scholar?hl=fr\&as_sdt=0\%2C\&q =1.\%0Rahbani\%2C+J.N.\%3B+Salameh\%2C+D.F.\%3B+Rahbani\% (accessed on 18 December 2019).

18. Chader, S.; Mahmah, B.; Chetehouna, K.; Mignolet, E. Biodiesel production using Chlorella sorokiniana a green microalga. Rev. Energ. Renouvelables 2011, 14, 21-26.

19. Béliveau, M.-O.; Bertrand-Lehouillier, V.; Carrier, J.; Tremblay, J.; Larrivée, M. Optimisation de la Culture de Microalgues Pour la Production de Biodiesel. 2013. Available online: https://scholar.google.com/scholar?hl=fr \&as_sdt $=0 \% 2 \mathrm{C} \& \mathrm{q}=1 . \% 0 \mathrm{~B} \% \mathrm{C} \%$ Aliveau $\% 2 \mathrm{C}+\mathrm{M} .-\mathrm{O} . \% 3 \mathrm{~B}+$ Bertrand-Lehouillier $\% 2 \mathrm{C}+\mathrm{V} . \% 3 \mathrm{~B}+$ Carrier $\% 2 \mathrm{C}+\mathrm{J}$ $\% 3 \mathrm{~B}+$ Tremblay $\% 2 \mathrm{C}+\mathrm{J} . \% 3 \mathrm{~B}+$ Larriv $\% \mathrm{C} \% \mathrm{Ae} \% 2 \mathrm{C}+\mathrm{M}$.+Optimisation+de+la+Culture+de+Microalgues+Pour + la+Production + de+Biodiesel\%3B+2.\&btnG= (accessed on 18 December 2019).

20. Chamoumi, M.; Faucheux, N.; Jones, J.P.; Brunel, D. Optimisation de la Production du Biodiesel à Partir d'huiles de Microalgues et d'huiles Usées. Producteur non Identifié. Ph.D. Thesis, Centre universitaire de Formation en Environnement, Sherbrooke, QC, Canada, 2013.

21. Massart, A.; Aubry, É.; Hantson, A.-L. Étude de stratégies de culture de Dunaliella tertiolecta combinant haute densité cellulaire et accumulation de lipides en vue de produire du biodiesel. BASE 2010, 14. Available online: https://scholar.google.com/scholar?hl=fr\&as_sdt=0\%2C\&q=2.\%0Massart $\% 2 \mathrm{C}+\mathrm{A} . \% 3 \mathrm{~B}+\mathrm{Aubry} \% 2 \mathrm{C}$ $+\% \mathrm{C} \% 8 . \% 3 \mathrm{~B}+$ Hantson $\% 2 \mathrm{C}+\mathrm{A} .-\mathrm{L} .+\% \mathrm{C} \% 8$ tude+de+strat $\% \mathrm{C} \%$ Agies+de+culture+de+Dunaliella+tertiolecta +combinant+haute+densit $\% \mathrm{C} \% \mathrm{~A}+$ cellulaire+et+accumulation+de+lipides+en+vue+de+produire+du+biod iesel.+BASE+2\%2C+1.\&btnG = (accessed on 18 December 2019).

22. Olofsson, M.; Lamela, T.; Nilsson, E.; Bergé, J.P.; Del Pino, V.; Uronen, P. Seasonal variation of lipids and fatty acids of the microalgae Nannochloropsis oculata grown in outdoor large-scale photobioreactors. Energies 2012, 5, 1577-1592. [CrossRef]

23. Branco-Vieira, M.; San Martin, S.; Agurto, C.; Santos, M.A.; Freitas, M.A.; Mata, T.M. Potential of Phaeodactylum tricornutum for biodiesel production under natural conditions in Chile. Energies 2018, 11, 54. [CrossRef]

24. Casadevall, E.; Bailliez, C.; Berkaloff, C.; Brenckmann, F.; Chirac, C.; Corre, B. Production of renewable hydrocarbons through the culture of green unicellular alga Botryococcus: Study of the factors affecting the production of hydrocarbons: Final report. Production d'hydrocarbures renouvelables par la culture de l'algue verte botryococcus braunii: Etude des facteurs affectant la production des hydrocarbures: Rapport final. 1985. Available online: https://www.osti.gov/etdeweb/biblio/ (accessed on 18 December 2019). 
25. Panouillé, M.; Larreta-Garde, V. Gelation behaviour of gelatin and alginate mixtures. Food Hydrocoll. 2009, 23, 1074-1080.

26. Khromova, Y.L. The effect of chlorides on alginate gelation in the presence of calcium sulfate. Colloid J. 2006, 68, 115-119. [CrossRef]

27. Polona, S.; Marija, B.; Anamarija, Z.; Odon, P.; Ales, M. Shape optimization and characterization of polysaccharide beads prepared by ionotropic gelation. J. Microencapsul. 2007, 25, 90-105.

28. Benasla, A.; Hausler, R. Optimisation of Growth of Raphidocelis subcapitata Immobilised for Biofuel Production: Influence of Alginate and $\mathrm{CaCl} 2$ Concentrations on Growth. Environments 2018, 5, 60. [CrossRef]

29. Environnement et changement climatique Canada. Méthode d'essai Biologique: Essai d'inhibition de la Croissance d'une Algue d'eau Douce.Centre des Sciences et Technologies Environnementales; Environnement et changement climatique Canada: Ottawa, ON, Canada, 2007.

30. Santos, M.M.D.; Moreno-Garrido, I.; Gonçalves, F.; Soares, A.M.; Ribeiro, R. An in situ bioassay for estuarine environments using the microalga Phaeodactylum tricornutum. Environ. Toxicol. Chem. 2002, 21, 567-574. [CrossRef] [PubMed]

31. Voo, W.-P.; Lee, B.-B.; Idris, A.; Islam, A.; Tey, B.-T.; Chan, E.-S. Production of ultra-high concentration calcium alginate beads with prolonged dissolution profile. RSC Adv. 2015, 5, 36687-36695. [CrossRef]

32. Lam, M.K.; Lee, K.T. Immobilization as a feasible method to simplify the separation of microalgae from water for biodiesel production. Chem. Eng. J. 2012, 191, 263-268. [CrossRef]

33. Richmond, A. Handbook of Microalgal Culture: Biotechnology and Applied Phycology; John Wiley \& Sons: Hoboken, NJ, USA, 2008.

34. Van Vooren, G.; Le Grand, F.; Legrand, J.; Cuiné, S.; Peltier, G.; Pruvost, J. Investigation of fatty acids accumulation in Nannochloropsis oculata for biodiesel application. Bioresour. Technol. 2012, 124, 421-432. [CrossRef]

35. Folch, J.; Lees, M.; Stanley, G.S. A simple method for the isolation and purification of total lipides from animal tissues. J. Biol. Chem. 1957, 226, 497-509.

36. Bligh, E.G.; Dyer, W.J. A rapid method of total lipid extraction and purification. Can. J. Biochem. Physiol. 1959, 37, 911-917. [CrossRef]

37. Eaton, A.D.; Clesceri, L.S.; Rice, E.W.; Greenberg, A.E.; Franson, M. APHA: Standard Methods for the Examination of Water and Wastewater, Centennial ed.; APHA: Washington, DC, USA, 2005.

38. Murphy, J.; Riley, J.P. A modified single solution method for the determination of phosphate in natural waters. Anal. Chim. Acta 1962, 27, 31-36. [CrossRef]

39. Del Río, E.; Armendáriz, A.; García-Gómez, E.; García-González, M.; Guerrero, M.G. Continuous culture methodology for the screening of microalgae for oil. J. Biotechnol. 2015, 195, 103-107. [CrossRef]

40. Rodolfi, L.; Chini Zittelli, G.; Bassi, N.; Padovani, G.; Biondi, N.; Bonini, G. Microalgae for oil: Strain selection, induction of lipid synthesis and outdoor mass cultivation in a low-cost photobioreactor. Biotechnol. Bioeng. 2009, 102, 100-112. [CrossRef]

41. Bernard, O.; Blonz, C.; Hidoine, B. Projet Shamash: Production de Biocarburants Lipidiques par des Microalgues. 2008. Available online: https://scholar.google.com/scholar?hl=fr\&as_sdt=0\%2C\&q=4. $\% 0$ Berna rd $\% 2 \mathrm{C}+\mathrm{O} . \% 3 \mathrm{~B}+\mathrm{Blonz} \% 2 \mathrm{C}+\mathrm{C} . \% 3 \mathrm{~B}+$ Hidoine $\% 2 \mathrm{C}+\mathrm{B} .+$ Projet+Shamash $\% 3 \mathrm{~A}+$ Production + de + Biocarbura nts+Lipidiques+par+des+Microalgues\%3B+\&btnG= (accessed on 17 December 2019).

42. Dejoye, C. Eco-Extraction et Analyse de Lipides de Micro-Algues Pour la Production D'algo-Carburant; Université d'Avignon: Avignon, France, 2013.

43. Hersant, G.; Tremblay, A.; Berthelot, L.; Rousseau, J.; Bernier, R. Merinov; ÉPAQ: Grande-Rivière, QC, Canada, 2012.

44. Del Río, E.; García-Gómez, E.; Moreno, J.; Guerrero, M.G.; García-González, M. Microalgae for oil. Assessment of fatty acid productivity in continuous culture by two high-yield strains, Chlorococcum oleofaciens and Pseudokirchneriella subcapitata. Algal Res. 2017, 23, 37-42. [CrossRef]

(C) 2020 by the authors. Licensee MDPI, Basel, Switzerland. This article is an open access article distributed under the terms and conditions of the Creative Commons Attribution (CC BY) license (http://creativecommons.org/licenses/by/4.0/). 